\title{
PENGARUH CORPORATE GOVERNANCE TERHADAP TAX AVOIDANCE: STUDI EMPIRIS PADA PERUSAHAAN MANUFAKTUR
}

\author{
Syeldila Sandy \\ Jurusan Akuntansi, Fakultas Ekonomi, Universitas Andalas, Padang \\ e-mail: syeldilasandy@gmail.com \\ Niki Lukviarman \\ Jurusan Akuntansi, Fakultas Ekonomi, Universitas Andalas, Padang \\ e-mail: lukviarman@gmail.com
}

\begin{abstract}
The purpose of the study was to investigate the effect of corporate governance on tax avoidance. The secondary data for the study were collected from manufacturing companies that listed in Indonesian Stock Exchange in the period of 2011-2013 by using purposive sampling technique. In order to test hypotheses, the study performed multiple regression analysis. The results indicated that proportion of independent commissioner, audit quality, and audit committee had a negative and significant affect on tax avoidance, while institutional ownership was not consider as a determinant of tax avoidance in Indonesian manufacturing firms.
\end{abstract}

Keywords: Corporate Governance and Tax Avoidance.

http://dx.doi.org/10.20885/jaai.vol19.iss2.art1

\begin{abstract}
Abstrak
Tujuan dari penelitian ini adalah untuk mengetahui pengaruh corporate governance pada penghindaran pajak. Data sekunder untuk penelitian ini dikumpulkan dari perusahaan manufaktur yang terdaftar di Bursa Efek Indonesia pada periode 2011-2013 dengan menggunakan teknik purposive sampling. Untuk menguji hipotesis, penelitian ini dilakukan analisis regresi ganda. Hasil penelitian menunjukkan bahwa proporsi komisaris independen, kualitas audit, dan komite audit memiliki pengaruh negatif dan signifikan terhadap penghindaran pajak, sementara kepemilikan institusional tidak menganggap sebagai penentu penghindaran pajak di perusahaan manufaktur Indonesia.
\end{abstract}

Kata kunci: Corporate Governance dan Penghindaran Pajak.

\section{PENDAHULUAN}

Penerimaan sektor pajak memainkan peran penting dalam pembiayaan belanja negara. Mayoritas pembiayaan belanja Indonesia di biayai dari penerimaan pajak. Berdasarkan data sekunder tahun 2011-2013 ditemukan rata-rata kontribusi penerimaan pajak terhadap APBN adalah $69,38 \%$, kontribusi penerimaan non-pajak adalah 30,38\%, hibah sebesar 0,24\% (www.fiskal.depkeu.go.id). Fakta yang ditenukan selama $\mathrm{t}$ ahun 2011-2013 memperlihatkan bahwa peran penting pajak tidak berbanding lurus dengan realisasi penerimaan pajak. Realisasi penerimaan pajak tidak pernah mencapai target yang ditetapkan dan bahkan mengalami penurunan secara terus menerus. Kondisi ini merupakan indikasi tingginya praktik penghindaran pajak (tax avoidance) oleh wajib pajak.

Tax avoidance merupakan segala sesuatu yang dilakukan perusahaan yang berakibat pada pengurangan terhadap pajak perusahaan (Dyreng, Hanlon, dan Maydew 2008). Motif perusahaan pada praktek ini adalah upaya memperbesar keuntungan yang diharapkan oleh pemegang saham, dan pelaksanaannya dilakukan oleh manajer (Desai dan Dharmapala 2006). Praktek penghindaran pajak membuka peluang bagi manajer untuk bersikap oportunis untuk tujuan keuntungan 
jangka pendek yang kemungkinan besar akan merugikan pemegang saham dalam jangka panjang (Minnick dan Noga 2010). Corporate Governance (CG) berperan penting dalam mengendalikan akibat dari permasalah agensi dalam praktek penghindaran pajak (Desai dan Dharmapala 2006; Armstrong et al. 2013).

Lukviarman (2006) menjelaskan CG adalah mekanisme untuk melakukan sesuatu yang benar dengan cara yang benar (doing the right things right). Manusia itu bersifat oportunistik, yaitu kecendrungan untuk memanfaatkan kesempatan dengan tujuan memperoleh keuntungan dari suatu posisi atau keadaan tertentu, namun dengan merugikan pihak lainnya. Manipulasi data keuangan untuk kepentingan tertentu merupakan tindakan yang tidak benar (Lukviarman 2006).

Penelitian menganai tax avoidance telah menjadi perhatian para peneliti dalam satu dekade terakhir (Desai dan Dharmapala 2006; Minnick dan Noga 2010; James dan Igbeng 2014; Fernandes, Martinez, dan Nossa 2013; Armstrong et al. 2013; Khoala 2013; Rego dan Wilson 2008; Sabli dan Noor 2012). Namun literatur terdahulu menunjukkan pandangan yang berbeda-beda terkait faktor determinan tax avoidance. Ketidak konsistenan tersebut cenderung disebabkan oleh masih lemahnya konsep dan pengukuran tax avoidance serta tidak relevannya dalam praktek (Desai dan Dharmapala 2006). Oleh karena itu, dibutuhkan suatu model yang parsimoni sehingga dapat dipahami dan diimplementasikan oleh praktisi secara sederhana.

Disisi lain, CG telah teridentifikasi sebagai variabel penting yang menjelaskan variasi tax avoidance (James dan Igbeng 2014; Armstrong et al. 2013). Namun hasil penelitian empiris menunjukkan hubungan antara CG dan tax avoidance masih belum konklusif. Beberapa peneliti terdahulu menemukan variabel $\mathrm{CG}$ tidak berpengaruh terhadap tax avoidance (Khoala 2013; Rego dan Wilson 2008; Sabli dan Noor 2012; Kurniasih dan Sari 2013; Maharani dan Suardana 2014; Dewi dan Jati 2014; Prakosa 2014), sementara para peneliti lain menemukan bahwa CG memiliki dampak yang negatif dan signifikan terhadap tax avoidance (Armstrong et al. 2013; Desai dan Dharmapala 2006; Minnick dan Noga 2010; James dan Igbeng 2014; Darmawan dan Sukartha 2014; Fernandes, Martinez, dan Nossa 2013).

Hal yang menarik untuk dipahami bahwa kebanyakan penelitian empiris tentang hubungan antara $\mathrm{CG}$ dan tax avoidance didominasi pada negara-negara maju (Desai dan Dharmapala 2006; Minnick dan Noga 2010; James dan Igbeng 2014; Fernandes, Martinez, dan Nossa 2013; Armstrong et al. 2013; Khoala 2013; Rego dan Wilson 2008; Sabli dan Noor 2012), sementara di negara berkembang khususnya Indonesia masih sangat terbatas. Dengan demikian tujuan penelitian ini adalah untuk menguji secara empiris pengaruh $\mathrm{CG}$ terhadap tax avoidance pada perusahaan manufatur di Indonesia.

\section{TINJAUAN PUSTAKA DAN PERUMUSAN HIPOTESIS}

\section{Tax Avoidance}

Tax avoidance merupakan segala bentuk kegiatan yang memberikan efek terhadap kewajiban pajak, baik kegiatan diperbolehkan oleh pajak atau kegiatan khusus untuk mengurangi pajak. Biasanya tax avoidance dilakukan dengan memanfaatkan kelemahan-kelemahan hukum pajak yang terkesan tidak melanggar hukum perpajakan (Dyreng, Hanlon, dan Maydew 2008). Menurut Shafer dan Simmons (2006) tax avoidance adalah suatu skema transaksi yang ditujukan untuk meminimalkan beban pajak dengan memanfaatkan berbagai kelemahan (loophole) ketentuan perpajakan suatu negara sehingga ahli pajak menyatakan legal karena tidak melanggar peraturan perpajakan. Dengan demikian dapat disimpulkan tax avoidance adalah tindakan legal atau boleh dilakukan oleh wajib pajak dengan memanfaatkan kelemahan dari Undang-Undang yang berlaku untuk mengurangi beban pajak perusahaan.

\section{Corporate Governance}

Good Corporate Governance di defenisikan sebagai The blend of law, regulation and 
appropriate voluntary private sector practices, Which enable a corporation to attact financial and human capital, perform efficiently and thereby prepetuale it self by generating long term economic value for its shareholders and society of the whole (Wardani 2008).

Lukviarman (2006) mendefinisikan CG adalah mekanisme untuk melakukan sesuatu yang benar, secara benar (doing the right things right). CG memberikan penekanan pada the right things sebelum dikerjakan secara benar. Berdasarkan pendapat diatas maka dapat disimpulkan bahwa implementasi CG harus menekankan pada melakukan sesuatu yang benar dengan cara-cara yang benar. sehingga tidak ada pihak yang merasa dirugikan. Prinsip CG di Indonesia dengan Keputusan Menteri BUMN No. Kep16/MMBU/2012 tentang penerapan praktik good corporate governance pada BUMN pada Bab II pasal 3 meliputi lima prinsip yaitu: (1) Transparency, (2) Accountability (3) Responsibility, (4) Independency, dan (5) Fairness.

Kehadiran CG yang baik bagi suatu perusahaan akan menunjang aktivitas operasional, selain itu mekanisme pelaksanaan CG suatu perusahaan harus menjadi perhatian utama perusahaan demi kelancaran kegiatan dalam perusahaan. Mekanisme CG yang baik memiliki keterkaitan dengan kemakmuran perusahaan dan para pemegang saham, sehingga penerapannya diharapkan memberikan kontribusi positif bagi perusahaan secara keseluruhan. Dalam penelitian empiris, para peneliti terdahulu melakukan pengukuran CG dengan cara yang berbeda. Dalam penelitian ini penulis menggunakan 4 (empat) variabel yaitu kepemilikan institusional, proporsi komisaris independen, kualitas audit, dan komite audit.

\section{Kepemilikan Institutional}

Kepemilikan Institusional adalah kepemilikan saham yang dimiliki oleh institusi seperti asuransi, bank, perusahaan investasi dan kepemilikan institusi lain (Tarjo 2008). Kepemilikan saham instiusional adalah prosentase saham yang dimiliki institusi dan kepemilikan blockholder, yaitu kepemilikan individu atau atas nama perorangan diatas lima persen $(5 \%)$ tetapi tidak termasuk dalam golongan kepemilikan insider atau manajerial. Terdapat beberapa kelebihan Kepemilikan institusional antara lain: (1) Memiliki profesionalisme dalam menganalisis informasi sehingga dapat menguji keandalan informasi. (2) Memiliki motivasi yang kuat untuk melaksanakan pengawasan lebih ketat atas aktivitas yang terjadi di dalam perusahaan.

Kepemilikan Institusional dapat diukur dengan cara jumlah kepemilikan saham oleh investor institusi terhadap total jumlah saham yang beredar (Khurana dan Moser 2009; Annisa dan Kurniasih 2012). Investor institusi yang dimaksud adalah perusahaan lain yang memiliki saham pada korporasi tertentu dimana indikatornya adalah persentase saham yang dimiliki investor institusi tersebut dibandigkan dengan jumlah saham korporasi yang beredar.

\section{Proporsi Komisaris Independen}

Komisaris adalah organ perseroan yang bertugas mengawasi secara umum dan atau khusus sesuai dengan anggaran dasar dan memberi nasehat pada direksi (UU PT No. 40 Tahun 2007). Komisaris Independen didefinisikan sebagai seorang yang tidak terafiliasi dalam segala hal dengan pemegang saham pengendali, tidak memiliki hubungan afiliasi dengan direksi atau komisaris serta tidak menjabat sebagai direktur pada suatu perusahaan yang terkait dengan perusahaan pemilik menurut peraturan yang dikelurkan oleh BEI (Pohan 2008). Jumlah Komisaris Independen proporsional dengan jumlah saham yang dimiliki oleh pemegang saham yang tidak berperan sebagai pengendali dengan ketentuan jumlah Komisaris Independen sekurangkurangnya tiga puluh persen $(30 \%)$ dari seluruh anggota komisaris, disamping hal itu Komisaris Independen memahami undangundang dan peraturan tentang pasar modal serta diusulkan oleh pemegang saham yang bukan merupakan pemegang saham pengendali dalam Rapat Umum Pemegang Saham. Pengukuran variabel proporsi Komisaris 
Independen dapat dilakukan dengan cara perbandingan jumlah komisaris independen dengan jumlah Dewan Komisaris (Siallagan dan Machfoedz 2006; Mayangsari 2003).

\section{Kualitas Audit}

Dalam penerapan CG, Kualitas Audit dengan pengungkapkan yang akurat (transparansi) menjadi salah satu elemen yang penting. Menurut Sartori (2010), transparansi terhadap pemegang saham dapat dicapai dengan melaporkan hal-hal terkait perpajakan pada pasar modal dan pertemuan para pemegang saham, alasannya adalah adanya asumsi bahwa implikasi dari perilaku pajak yang agresif, pemegang saham tidak ingin perusahaan mereka mengambil posisi agresif dalam hal pajak dan akan mencegah tindakan tersebut jika mereka tahu sebelumnya.

Laporan keuangan memiliki peranan yang penting dan merupakan dasar pengambilan keputusan bagi investor. Oleh karena itu kualitas laporan keuangan perusahaan dapat dilihat dari apakah perusahaan tersebut menggunakan Kantor Akuntan Publik (KAP) Big Four dalam mengaudit laporan keuangannya atau tidak. KAP The Big Four adalah oligopoly industry akuntansi dan jasa professional karena mereka menguasai sebagian besar pasar, yaitu perusahaan go public (terdaftar di pasar modal) di seluruh dunia, dan perusahaan private besar lainnya. Laporan keuangan yang diaudit oleh auditor KAP The Big Four dipercaya lebih berkualitas sehingga menampilkan nilai perusahaan yang sebenarnya, oleh karena itu diduga perusahaan yang diaudit oleh KAP The Big Four (PriceWaterhouseCooper-PWC, Deloitte Touche Tohmatsu, KPMG, Ernst \& YoungE\&Y) memiliki tingkat kecurangan yang lebih rendah dibandingkan dengan perusahaan yang diaudit oleh KAP non The Big Four. Sebab Auditor yang memiliki kemampuan dan kualitas yang tinggi akan mempertahankan reputasinya dengan memberikan Kualitas Audit yang tinggi pula.

Kualitas Audit dapat diukur dengan menggunakan proksi ukuran Kantor Akuntan Publik (KAP), apakah KAP tersebut masuk dalam KAP The Big Four atau tidak (Setiana dan Setyowati 2014). Variabel ini diukur dengan variable dummy, angka dua untuk perusahaan yang diaudit dengan KAP Big Four angka satu untuk perusahaan yang diaudit dengan KAP non The Big Four.

\section{Komite Audit}

Komite Audit memiliki peran penting sebagai salah satu organ perusahaan yang mutlak harus ada dalam penerapan good corporate governance (GCG). Menurut Daniri (2006), sejak direkomendasikan GCG di Bursa Efek Indonesia (BEI) tahun 2000, Komite Audit telah menjadi komponen umum dalam struktur CG perusahaan publik. Pada umumnya, komite ini berfungsi sebagai pengawas proses pembuatan laporan keuangan dan pengawasan internal, karena BEI mengharuskan semua emiten untuk membentuk dan memiliki komite audit yang diketuai oleh Komisaris Independen.

Pohan (2008) dalam penelitiannya memaparkan bahwa Dewan Komisaris wajib membentuk Komite Audit yang beranggotakan sekurang-kurangnya tiga orang anggota, diangkat dan diberhentikan serta bertanggung jawab kepada Dewan Komisaris. Komite Audit yang beranggotakan sedikit, cenderung dapat bertindak lebih efisien, namun juga memililki kelemahan, yakni minimnya ragam pengalaman anggota, sehingga anggota Komite Audit seharusnya memiliki pemahaman memadai tentang pembuatan laporan keuangan dan prinsip-prinsip pengawasan internal. Kualifikasi terpenting dari anggota Komite Audit terletak pada common sense, kecerdasan dan suatu pandangan yang independen. Tujuan pembentukan Komite Audit adalah: (1) Memastikan laporan keuangan yang dikeluarkan tidak menyesatkan dan sesuai dengan praktik akuntansi yang berlaku umum; (2) Memastikan bahwa control internalnya memadai; (3) Tindak lanjut terhadap dugaan adanya penyimpangan yang material dibidang keuangan dan implikasi hukumnya; (4) Merekomendasikan seleksi auditor eksternal. 


\section{Pengembangan Hipotesis}

\section{Kepemilikan Institutional dan Tax Avoidance}

Perusahaan yang kepemilikan sahamnya lebih besar dimiliki oleh institusi perusahaan lain maupun pemerintah, maka kinerja dari manajemen perusahaan untuk dapat memperoleh laba sesuai dengan yang diinginkan akan cenderung di awasi oleh investor institusi tersebut. Hal tersebut mendorong manajemen untuk dapat meminimalkan nilai pajak yang terutang oleh perusahaan. Penelitian yang dilakukan oleh Shafer dan Simmons (2006) menemukan bahwa Kepemilikan Institusional memainkan peran penting dalam memantau, mendisiplinkan dan mempengaruhi manajer dalam manajemen pajak.

Argumentasi di atas didukung oleh penelitian Khurana dan Moser (2009) yang menemukan besar atau kecilnya konsentrasi Kepemilikan Institusional akan mempengaruhi kebijakan penghindaran pajak oleh perusahaan, dimana apabila semakin besarnya konsentrasi kepemilikan saham jangka pendek (short-term Shareholder) institusional, maka akan meningkatkan penghindaran pajak, tetapi apabila semakin besar konsentrasi kepemilikan saham jangka panjang (longterm shareholder) maka akan semakin mengurangi tindakan kebijakan penghindaran pajak.

H1: Kepemilikan Institutional berpengaruh negatif dan signifikan terhadap tax avoidance

\section{Proporsi Komisaris Independen dan Tax Avoidance}

Dari perspektif teori agensi, anggota Dewan Komisaris yang berasal dari luar perusahaan (Komisaris Independen) berperan untuk mengawasi jalannya peran eksekutif yang lain (Solomon 2007). Apabila tidak ada pengawasan dari Komisaris Independen, maka akan semakin besar kemungkinan eksekutif yang lain dapat memanipulasi posisi mereka dengan mendapatkan kontrol yang penuh atas remunerasi mereka sendiri dan mengamankan jabatan mereka (Solomon 2007), sehingga dapat merugikan pemegang saham. Sebaliknya, semakin besar Proporsi Komisaris Independen, maka akan dapat meningkatkan kinerja dan kekayaan pemegang saham (Minnick dan Noga 2010). Sedangkan dari perspektif stakeholder, keberadaan Komisaris Independen dalam perusahaan merupakan strategi stakeholder untuk ikut memberi pengaruh dan mengawasi perusahaan sehingga memberi keuntungan bagi stakeholder. Beberapa penelitian terdahulu menemukan bahwa Proporsi Komisaris Independen berpengaruh negatif dan signifikan terhadap tax avoidance (Timothy 2010; Lanis dan Richardson 2011; Setiana dan Setyowati 2014; Maharani dan Suardana 2014; Prakosa 2014).

H2: Proporsi Komisaris Independen berpengaruh negatif dan signifikan terhadap tax avoidance

\section{Kualitas Audit dan Tax Avoidance}

Dalam implementasi CG, Kualitas Audit dengan pengungkapkan yang transparan (transparancy) menjadi salah satu elemen yang penting. Transparansi terhadap pemegang saham dapat dicapai dengan melaporkan hal-hal terkait perpajakan pada pasar modal dan pertemuan para pemegang saham. Peningkatan transparansi dalam hal pajak kepada pemegang saham semakin dituntut oleh otoritas publik (Sartori 2010).

Auditor yang memiliki kemampuan dan kualitas kerja yang tinggi akan mempertahankan reputasinya dengan memberikan kualitas audit yang tinggi pula. Perusahaan yang memilih menggunakan jasa auditor yang berkualitas dapat menjamin informasi keuangan yang dilaporkan kepada investor. Konsekuensinya investor akan lebih percaya atas informasi tersebut (Tuanakotta 2007) dan tentnya akan dapat menceg ah perilaku penghindaran pajak.

Perusahaan yang diaudit oleh Kantor Akuntan Publik (KAP) The Big Four biasanya menghasilkan kualitas audit yang semakin baik, dan akan semakin sulit melakukan kebijakan penghindaran pajak. Dengan demikian, apabila semakin berkualitas audit suatu perusahaan, maka perusahaan tersebut cenderung tidak melakukan manipulasi laba untuk kepentingan perpajakan (Chai dan Liu 2009). Secara empiris, para peneliti terdahulu telah 
membuktikan bahwa Kualitas Audit memiliki pengaruh yang negatif dan signifikan terhadap tax avoidance (Annisa dan Kurniasih 2012; Maharani dan Suardana 2014; Dewi dan Jati 2014).

H3: Kualitas Audit berpengaruh negatif dan ' signifikan terhadap tax avoidance

\section{Pengaruh Komite Audit terhadap Tax}

\section{Avoidance}

Komite Audit adalah orang atau sekelompok orang sekurang kurangnya tiga orang yang independen di dalam perusahaan yang dipilih juga secara independen yang mempunyai kapabilitas dan kompetensi dalam bidang akuntansi dan keuangan, komite audit bertanggung jawab kepada dewan komisaris (Pohan 2008). Komite Audit berfungsi memberikan pandangan mengenai masalah-masalah yang berhubungan dengan kebijakan keuangan, akuntansi dan pengendalian internal perusahaan (Mayangsari 2003).

Sementara BEI mensyaratkan paling sedikit Komite Audit harus tiga orang. Jadi jika kurang dari tiga orang maka tidak sesuai dengan peraturan BEI. Dengan demikian, apabila jumlah komite audit dalam suatu perusahaan tidak sesuai dengan peraturan BEI maka akan meningkatkan tindakan manajemen dalam melakukan minimalisasi laba untuk kepentingan penghindaran pajak (tax avoidance).

Secara empiris, para peneliti terdahulu telah membuktikan bahwa Komite Audit memiliki pengaruh yang bermakna terhadap pengindaran pajak atau tax avoidance (Maharani dan Suardana 2014; Dewi dan Jati 2014; Annisa dan Kurniasih 2012).

H4: Komite Audit berpengaruh negatif dan signifikan terhadap tax avoidance

\section{METODA PENELITIAN}

\section{Populasi dan Sampel}

Populasi dalam penelitian ini adalah perusahaan manufaktur yang terdaftar di Bursa Efek Indonesia (BEI) pada periode 2011-2013. Teknik penarikan sampel (sampling teqnique) yang digunakan adalah purposive sampling yaitu metode penarikan sampel berdasarkan kriteria tertentu yang ditetapkan oleh peneliti (Sekaran and Bougie 2010). Adapun kriteria yang ditetapkan sebagai berikut: (1) Perusahaan memuat dan mempublikasikan laporan keuangan yang berakhir 31 Desember periode 2011-2013; (2) Laporan keuangan tahunan disajikan menggunakan mata uang Rupiah. Penggunaan satuan mata uang selain Rupiah, meskipun dapat dikonversi, dapat menimbulkan perbedaan akibat kurs yang terus berubah; (3) Perusahaan manufaktur yang tidak mengalami rugi periode 2011-2013; (4) Perusahaan yang memiliki data mengenai Kepemilikan Institusional, Komisaris Independen, Komite Audit, dan informasi KAP yang mengaudit perusahaan.

\section{Teknik Pengumpulan Data}

Untuk memperoleh data yang dibutuhkan dalam penelitian ini penulis menggunakan teknik dokumentasi dengan melihat laporan tahunan yang diterbitkan oleh perusahaan manufaktur dari tahun 2011 sampai 2013. Data diperoleh dari situs resmi Bursa Efek Indonesia (www.idx.co.id), web-web resmi perusahaan sampel, dan dengan cara mempelajari literatur yang berkaitan dengan permasalahan penelitian baik media cetak maupun elektronik.

\section{Definisi dan Operasional Variabel}

\section{Tax Avoidance (TA)}

Tax avoidance adalah usaha untuk mengurangi, atau bahkan meniadakan hutang pajak yang harus dibayar perusahaan dengan tidak melanggar undang-undang yang ada. Variabel ini di proksikan dengan menggunakan rumus Tarif Pajak Efektif (ETR). Tarif pajak efektif digunakan sebagai pengukuran karena dianggap dapat merefleksikan perbedaan tetap antara perbedaan laba buku dan laba fiskal. Tarif Pajak Efektif (ETR) dihitung dengan menggunakan cara membagi total beban pajak perusahaan dengan laba sebelum pajak penghasilan.

$$
E T R=\frac{\text { Beban Pajak }}{\text { Laba Sebelum Pajak }}
$$




\section{Kepemilikan Institutional (KI)}

Besar kecilnya kepemilikan institusional maka akan mempengaruhi penghindaran pajak yang dilakukan oleh perusahaan. Dalam penelitian ini Kepemilikan Institusional diukur menggunakan presentase (Khurana and Moser 2009). Kepemilikan Institusional dapat diukur dengan menggunakan rasio sebagai berikut:

$$
\mathrm{KI}=\frac{\text { Saham yang dimiliki Institusi }}{\text { Jumlah Saham yang diterbitkan }}
$$

\section{Proporsi Komisaris Independen (PKI)}

Keberadaan variabel Proporsi Komisaris Independen yang menunjang kinerja perusahaan dan meningkatkan efektifitas aktifitas monitoring diukur dengan menggunakan persentase dewan komisaris yang ada dalam suatu perusahaan (Siallagan dan Machfoedz 2006). Dalam penelitian ini variabel Proporsi Komisaris Independen diproksikan dengan persentase keberadaan Komisaris Independen dalam suatu perusahaan (Siallagan dan Machfoedz 2006; Mayangsari 2003). Proporsi Dewan Komisaris Independen diukur dengan rasio sebagai berikut:

$$
\begin{aligned}
& \text { Jumlah Komisaris } \\
& \mathrm{PKI}=\frac{\text { Independen }}{\text { Jumlah Seluruh Dewan }} \times 100 \% \\
& \text { Komisaris }
\end{aligned}
$$

\section{Kualitas Audit (KualAudit)}

Kualitas audit biasa diukur berdasarkan besar atau kecilnya ukuran Kantor Akuntan Publik (KAP) yang melakukan audit pada suatu perusahaan. Jika perusahaan diaudit oleh KAP The Big Four, maka akan lebih independen karena lebih dapat bertahan dari tekanan manajer untuk melaporkan adanya pelanggaran (Kurniasih dan Sari 2013). Dalam penelitian ini perusahaan yang diaudit oleh KAP The Big Four yaitu Price Waterhouse Cooper-PWC, Deloitte Touche Tohmatsu, KPMG, Ernst \& Young-E\&Y akan diberi nilai 2, dan apabila tidak diaudit oleh keempat KAP di bawah lisensi KAP The Big Four akan diberi nilai 1.

\section{Komite Audit (KomAudit)}

Kehadiran Komite Audit diharapkan dapat memberikan pandangan mengenai masalah- masalah yang berhubungan dengan kebijakan keuangan, akuntansi dan pengendalian internal (Mayangsari 2003). Dalam penelitian ini Komite Audit diukur dengan menggunakan jumlah Komite Audit dalam suatu perusahaan. Berdasarkan Peraturan Bank Indonesia No. 8/14/PBI/2006 tentang pelaksanaan good corporate govenance jumlah anggota komite audit minimal 3 orang.

\section{Teknik Analisis Data}

\section{Uji Asumsi Klasik}

Tujuan menggunakan uji asumsi klasik adalah untuk memenuhi persyaratan dalam melakukan analisis regresi yang terdiri dari: (1) Uji Normalitas, bertujuan untuk menguji apakah dalam model regresi, variable-varibel yang diteliti terdistribusi secara normal atau tidak. pedoman yang dipakai untuk uji normalitas adalah uji Kolmogorov Smirnov, dimana kriteria uji Kolmogorov-Smirnov adalah jika nilai signifikasi lebih kecil dari tingkat signifikan yang digunakan $(\square 0,05)$ maka residual terdistribusi tidak normal, dan sebaliknya jika nilai signifikasi lebih besar dari tingkat signifikan yang digunakan $(\square 0,05)$ maka disimpulkan residual terdistribusi normal; (2) Uji Linearitas, bertujuan untuk melihat apakah spesifikasi model yang digunakan sudah benar atau tidak. Untuk menentukan apakah fungsi persamaan regresi yang digunakan berbentuk liner dapat dilihat dari nilai signifikan. Bila nilai signifikan lebih kecil dari 0,05 berarti persamaan regresi yang digunakan berbentuk linear dan sebaliknya; (3) Uji Multikolinearitas, bertujuan untuk menguji apakah model regresi ditemukan adanya korelasi yang kuat antar variabel bebas. Model regresi yang baik seharusnya tidak terjadi korelasi yang kuat antara variabel bebas. Adapun cara untuk mendeteksi ada atau tidaknya multikolinieritas di dalam model regresi melalui nilai tolerence dan variance inflation factor (VIF). Jika nilai VIF lebih kecil dari 10 dan tolerance lebih besar dari 0,10 maka model dinyatakan tidak terdapat gejala multikolonearitas; (4) Uji Autokolerasi, bertujuan untuk mengetahui ada atau tidak ada korelasi antar data berdasarkan urutan waktu. 
Metode yang digunakan adalah Durbin Watson (DW) dengan kriteria pengujiannya sebagai berikut: (a) Angka DW di bawah -2 maka terjadi autokorelasi positif, (b) Angka DW diantara -2 sampai dengan +2 maka tidak ada autokorelasi, dan (c) Angka DW di atas +2 maka terjadi autokorelasi negative.

\section{Multiple Regression Analysis}

Tujuan menggunakan multiple regression analysis dalam penelitian ini adalah untuk mengetahui pengaruh variabel CG terhadap tax avoidance dengan persamaan sebagai berikut: $\log \mathrm{TA}=\mathrm{a}-\mathrm{b} 1 \log \mathrm{KI}-\mathrm{b} 2 \log \mathrm{PDKI}-$ b3KualAudit - b4KomAudit + e (1)

Keterangan:

$$
\begin{array}{ll}
\log \mathrm{TA} & =\log \text { Tax Avoidance } \\
\mathrm{a} & =\text { Konstanta } \\
\mathrm{b} 1-4 & =\text { Koefesien regresi } \\
\mathrm{KI} & =\text { Kepemilikan Institutional } \\
\text { PKI } & =\text { Proporsi Komisaris Independen } \\
\text { KualAudit } & =\text { Kualitas Audit } \\
\text { KomAudit= Komite Audit }
\end{array}
$$

\section{HASIL DAN PEMBAHASAN}

\section{Statistik Deskriptif}

Statistik deskriptif berguna untuk mendeskripsikan variabel yang diteliti yaitu tax avoidance (TA) dan variabel corporate governance (CG).

Untuk menginterpretasikan implementasi CG maka skor range $(1,17)$ dibagi dengan 5 untuk menentukan interval masingmasing kategori yaitu Sangat Baik (1,4864 s/d 1,7204), Baik (1,2523 s/d 1,4863), Cukup Baik $(1,0182 \mathrm{~s} / \mathrm{d} 1,2522)$, Kurang Baik $(0,7841 \mathrm{~s} / \mathrm{d}$ 1,0181), dan Tidak Baik (0,5500 s/d 0,7840). Berdasarkan Tabel 1 dapat dilihat bahwa skor rata-rata (mean) variabel CG adalah 1,0007.
Temuan ini memberikan makna bahwa implementasi CG pada perusahaan sampel terpilih masuk kedalam kategori kurang baik.

Berdasarkan variabel CG, skor ratarata variabel Kepemilikan Institutional (KI) adalah 0,6681 yang bermakna bahwa rata-rata saham yang dimiliki oleh institusi adalah $66,81 \%$ dari jumlah saham yang beredar atau diterbitkan. Dari sisi variabel Proporsi Komisaris Independen (PKI) masih ditemukan adanya perusahaan sampel terpilih yang belum memenuhi ketentuan Bursa Efek Indonesia (BEI) yaitu sekurang-kurangnya $30 \%$ dari jumlah komisaris adalah Komisaris Independen yang ditunjukkan nilai minimal 0,2500 atau $25 \%$. Skor rata-rata variabel Kualitas Audit (KualAudit) ditemukan sebesar 1,49 dimana dari 150 data yang diamati terdapat sebanyak 77 data observasi $(51,3 \%)$ diaudit oleh Kantor Akuntan Publik (KAP) The Big Four yaitu Price Waterhouse Cooper-PWC, Deloitte Touche Tohmatsu, KPMG, Ernst \& Young-E\&Y, dan sebanyak 73 data observasi $(48,7 \%)$ diaudit oleh Non-Kantor Akuntan Publik (KAP) The Big Four. Variabel Komite Audit (KomAudit) skor rata-rata diperoleh sebesar 3,13 dengan skor minimum 2 dan maksimum 5. Hal ini bermakna bahwa masih ditemukan $(4,7 \%)$ data observasi yang belum memunuhi Peraturan Bank Indonesia No. 8/14/PBI/2006 tentang pelaksanaan Good corporate govenance jumlah anggota Komite Audit minimal 3 orang yang ditunjukkan dengan nilai minimal 2. Sementara skor ratarata variabel tax avoidance (TA) diperoleh sebesar 0,2789 yang bermakna bahwa tingkat perilaku penghindaran pajak pada perusahaan sampel terpilih sebesar $27,89 \%$.

Tabel 1: Deskripsi Variabel Penelitian ( $\mathrm{N}=150)$

\begin{tabular}{lllllll}
\hline No & Variabel & Mean & Median & Range & Min & Max \\
\hline 1 & Corporate Governance & 1,0007 & 1,0658 & 1,17 & 0,55 & 1,72 \\
& a. Kepemilikan Institutional & 0,6681 & 0,6275 & 0,5905 & 0,3711 & 0,9616 \\
& b. Proporsi Komisaris Independen & 0,3808 & 0,3333 & 0,5500 & 0,2500 & 0,8000 \\
& c. Kualitas Audit & 1,49 & 1,00 & 1 & 1 & 2 \\
& d. Komite Audit & 3,13 & 3,00 & 3 & 2 & 5 \\
2 & Tax Avoidance & 0,2798 & 0,2534 & 0,8695 & 0,0412 & 0,9107 \\
\hline
\end{tabular}

Sumber: Data yang diolah, 2015 


\section{Uji Asumsi Klasik}

Uji asumsi kalsik bertujuan untuk memenuhi persyaratan dalam melakukan analisis regresi. Persyaratan tersebut terdiri dari uji normalitas, linearitas, multikolinearitas, dan autokorelasi. Uji normalitas bertujuan untuk menguji apakah dalam model regresi, variabel-varibel yang diteliti terdistribusi secara normal atau tidak. Hasil uji normalitas dapat dilihat pada Tabel 2.

Berdasarkan Tabel 2 dapat dilihat bahwa nilai Asymp Sig adalah 0,460. Nilai signifikan terlebut lebih besar dari 0,05, sehingga dapat disimpulkan bahwa residual terdistribusi secara normal. Uji linearitas digunakan untuk melihat apakah spesifikasi model yang digunakan sudah benar atau tidak.
Untuk menentukan apakah fungsi persamaan regresi yang digunakan berbentuk liner dapat dilihat dari nilai signifikan. Hasil uji linearitas disajikan dalam Tabel 3.

Dari Tabel 3 dapat disimpulkan bahwa semua variabel CG (KI, PKI, Kualitas Audit, dan Komite Audit) memiliki hubungan linear dengan tax avoidance. Hal ini dapat dibuktikan dimana semua nilai signifikan lebih kecil dari 0,05. Uji multikolinearitas bertujuan untuk menguji apakah model regresi ditemukan adanya korelasi yang kuat antar variabel bebas. Model regresi yang baik seharusnya tidak terjadi korelasi yang kuat antara variabel bebas. Hasil uji multikolinearitas dapat dilihat pada Tabel 4.

Tabel 2: Hasil Uji Normalitas

One-Sample Kolmogrov-Smirnov Test

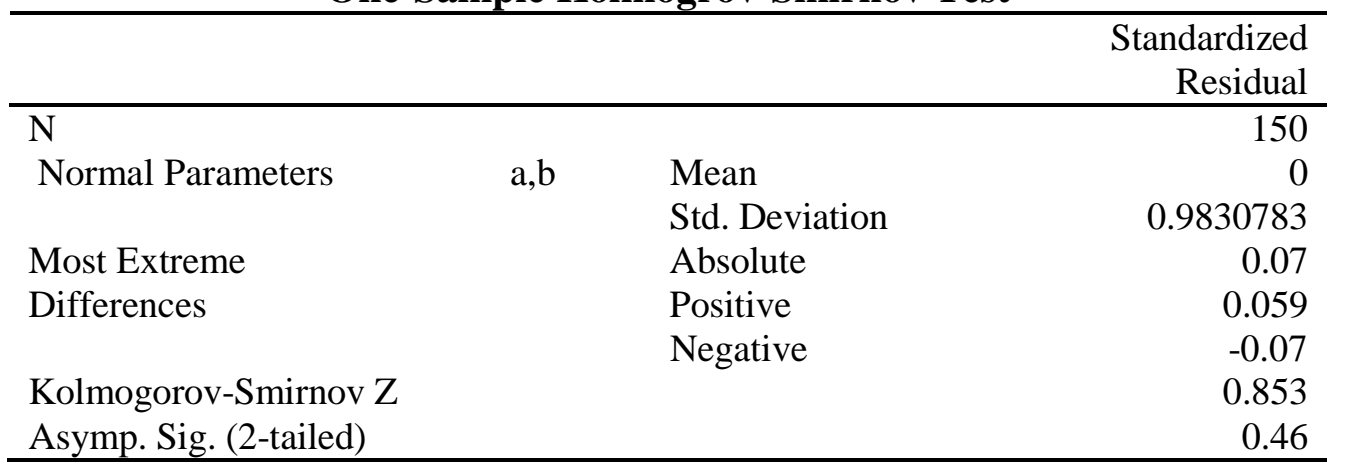

a. Test distribution is Normal.

b. Calculated from data.

Sumber: Data yang diolah, 2015

Tabel 3: Hasil Uji Linearitas

\begin{tabular}{lllll}
\hline No & Arah Hubungan & Cut-Off & Signifikan & Keterangan \\
\hline 1 & KI terhadap TA & 0,05 & 0,002 & Linear \\
2 & PKI terhadap TA & 0,05 & 0,000 & Linear \\
3 & KualAudit terhadap TA & 0,05 & 0,000 & Linear \\
4 & KomAudit terhadap TA & 0,05 & 0,000 & Linear \\
\hline
\end{tabular}

Sumber: Data yang diolah, 2015

Tabel 4: Hasil Uji Multikolinearitas

\begin{tabular}{cllllll}
\hline No & Variabel Bebas & Tolerance & Cut-Off & VIF & Cut-Off & Keterangan \\
\hline 1 & KI & 0,911 & 0,10 & 1,098 & 10 & Bebas Multikol \\
2 & PKI & 0,892 & 0,10 & 1,122 & 10 & Bebas Multikol \\
3 & KualAudit & 0,841 & 0,10 & 1,189 & 10 & Bebas Multikol \\
4 & KomAudit & 0,851 & 0,10 & 1,175 & 10 & Bebas Multikol \\
\hline
\end{tabular}

Sumber: Data yang diolah, 2015 
Tabel 5: Hasil Uji Autokorelasi

Model Summary b

\begin{tabular}{cccccc}
\hline Model & $\mathrm{R}$ & R Square & $\begin{array}{c}\text { Adjusted R } \\
\text { Square }\end{array}$ & $\begin{array}{c}\text { Std. Error of the } \\
\text { Estimate }\end{array}$ & Durbin-Watson \\
\hline 1 & $.686^{\mathrm{a}}$ & .471 & .456 & .13435 & 1.390 \\
\hline
\end{tabular}

a. Predictors: (Constant), KomAudit, LogKI, LogPDKI, KualAudit

b. Dependent Variable: $\log$ TA

Sumber: Data yang diolah, 2015

Dari tabel 4 dapat dilihat bahwa semua variabel bebas yaitu KI, PKI, KualAudit, dan KomAudit memiliki nilai tolerance lebih besar dari 0,10 dan nilai VIF lebih kecil dari 10 , sehingga dapat diartikan bahwa semua variabel bebas dalam penelitian ini dinyatakan bebas dari multikolinearitas. Hal ini berarti bahwa tidak terdapat korelasi yang kuat antar sesama variabel bebas. Uji autokorelasi bertujuan untuk mengetahui ada atau tidak ada korelasi antar data berdasarkan urutan waktu. Metode yang digunakan adalah Durbin Watson (DW). Hasil uji autokorelasi dapat dilihat pada Tabel 5.

Dari Tabel 5 dapat dilihat bahwa nilai Durbin-Watson (DW) adalah 1,390 yang berarti terletak antara -2 sampai dengan +2 sehingga dapat diartikan bahwa tidak ada autokorelasi atau tidak ada korelasi antar data berdasarkan urutan waktu.

\section{Multiple Regression Analysis}

Berdasarkan hasil analisis pada Tabel 6 dibawah dapat dikemukakan persamaan sebagai berikut:

$$
\begin{aligned}
\log \mathrm{TA}= & 0,350-0,220 \mathrm{X} 1-0,598 \log \mathrm{X} 2- \\
& 0,086 \mathrm{X} 3-0,132 \mathrm{X} 4+\mathrm{e}
\end{aligned}
$$

Koefisien regresi variabel log Kepemilikan Institutional (X1) ditemukan sebesar 0,220 dan signifikan 0,052 (lebih besar dari 0,05). Temuan ini dapat diartikan bahwa variabel Kepemilikan Institutional (X1) tidak berpengaruh signifikan terhadap tax avoidance (Y), sehingga H1 tidak dapat diterima atau ditolak. Koefisien regresi variabel log_Proporsi Komisaris Independen (X2) ditemukan sebesar -0,598 dan signifikan 0,000 (lebih kecil dari 0,05), sehingga $\mathrm{H} 2$ yang menyatakan "Proporsi Komisaris Independen berpengaruh negatif dan signifikan terhadap tax avoidance" dapat diterima.

Koefisien regresi variabel Kualitas Audit (X3) ditemukan sebesar -0,086 dan signifikan 0,000 (lebih kecil dari 0,05). Temuan ini dapat diartikan bahwa variabel Kualitas Audit (X3) berpengaruh negatif dan signifikan terhadap tax avoidance (Y), sehingga $\mathrm{H} 3$ dapat diterima. Koefisien regresi variabel Komite Audit (X4) ditemukan sebesar -0,132 dan signifikan 0,000 (lebih kecil dari 0,05). Temuan ini dapat diartikan bahwa variabel Komite Audit (X4) berpengaruh negatif dan signifikan terhadap tax avoidance (Y), sehingga $\mathrm{H} 4$ dapat diterima.

Tabel 6: Hasil Multiple Regression Analysis

\begin{tabular}{lccc}
\hline \multirow{2}{*}{ Variabel } & \multicolumn{2}{c}{ Tax Avoidance $(\mathbf{Y})$} & \multirow{2}{*}{ Keputusan } \\
\cline { 2 - 3 } & $\boldsymbol{\beta}$ & Sig. & \\
\hline Konstanta (a) & 0,350 & 0,000 & - \\
LogKI (X1) & $-0,220$ & 0,052 & H1 Ditolak \\
LogPKI (X2) & $-0,598$ & 0,000 & H2 Diterima \\
KualAudit (X3) & $-0,086$ & 0,000 & H3 Diterima \\
KomAudit (X4) & $-0,132$ & 0,000 & H4 Diterima \\
F Statistics & 32,225 & 0,000 & - \\
R2 & \multicolumn{2}{c}{0,471} & - \\
\hline
\end{tabular}

Sumber: Data yang diolah, 2015 
Nilai F statistik ditemukan sebesar 32,225 dan signifikan 0,000 (lebih kecil dari $0,05)$. Temuan ini dapat diartikan bahwa model penelitian tentang pengaruh variabel CG (Kepemilikan Institutional, Proporsi Komisaris Independen, Kualitas Audit, Komite Audit) terhadap tax avoidance dinyatakan layak. Sementara nilai R2 (R square) diperoleh sebesar 0,471 yang bermakna bahwa besarnya kontribusi atau pengaruh variabel CG (Kepemilikan Institutional, Proporsi Komisaris Independen, Kualitas Audit, Komite Audit) terhadap tax avoidance adalah $47,1 \%$.

\section{Pembahasan}

Hasil analisis deskriptif menemukan bahwa rata-rata tingkat penghindaran pajak yang dilakukan oleh perusahaan sampel terpilih adalah $27,98 \%$ dimana tingkat penghindaran pajak terendah adalah $4,12 \%$ dan tertinggi adalah $91,07 \%$. Rata-rata saham yang dimiliki oleh institusi adalah $66,81 \%$ dari jumlah saham yang beredar atau diterbitkan dimana kepemilikan saham institusi minimum $37,11 \%$ dan maksimum 96,16\%. Berdasarkan hasil pengujian hipotesis pertama (H1) diperoleh koefisien regresi variabel Kepemilikan Institutional (X1) sebesar -0,220 dan signifikan 0,052 . Nilai signifikan tersebut lebih besar dari 0,05. Dengan demikian dapat disimpulkan bahwa variabel Kepemilikan Institutional (X1) tidak berpengaruh signifikan terhadap tax avoidance (Y). Temuan penelitian ini bermakna bahwa tinggi atau rendahnya variasi penghindaran pajak (tax avoidance) tidak ditentukan oleh variabel Kepemilikan Intitutional. Dengan kata lain tinggi atau rendahnya persentase saham yang dimiliki institusi dibandingkan dengan jumlah saham yang diterbitkan atau saham beredar tidak akan memberikan dampak yang berarti terhadap perilaku penghindaran pajak. Temuan penelitian ini sejalan dengan hasil peneltian terdahulu (Maharani dan Suardana 2014; Dewi dan Jati 2014; Annisa dan Kurniasih 2012) dimana variabel Kepemilikan Institusional tidak berpengaruh signifikan terhadap tax avoidance.
Rata-rata jumlah komisaris independen pada perusahaan sampel terpilih adalah 38,08\% dari jumlah keseluruhan dewan komisaris. Walaupun demikian, masih ditemukan pada perusahaan sampel terpilih yang melanggar ketentuan yang ditetapkan oleh BEI yaitu jumlah komisaris independen sekurangkurangnya tiga puluh persen $(30 \%)$ dari seluruh anggota komisaris. Hal ini terbukti dengan diperolehnya skor minimal 0,2500 pada variabel Proporsi Komisaris Independen (X2). Berdasarkan hasil pengujian hipotesis kedua $(\mathrm{H} 2)$ diperoleh koefisien regresi variabel Proporsi Komisaris Independen (X2) sebesar -0,598 dan signifikan 0,000 dimana nilai signifikan tersebut lebih kecil dari 0,05. Dengan demikian dapat disimpulkan bahwa variabel Proporsi Komisaris Independen (X2) berpengaruh negatif dan signifikan terhadap tax avoidance (Y). Temuan penelitian ini bermakna bahwa tinggi atau rendahnya variasi penghindaran pajak (tax avoidance) ditentukan oleh variasi variabel Proporsi Komisaris Independen. Dengan kata lain, apabila semakin besar Proporsi Komisaris Independen maka akan semakin rendah tax avoidance. Namun sebaliknya, apabila semakin kecil Proporsi Komisaris Independen maka akan semakin tinggi tax avoidance. Temuan penelitian ini sejalan dengan hasil peneltian terdahulu (Timothy 2010; Lanis dan Richardson 2011; Setiana dan Setyowati 2014; Maharani dan Suardana 2014; Prakosa 2014) dimana para peneliti terdahulu tersebut menemukan bahwa variabel Proporsi Komisaris Independen berpengaruh negatif dan signifikan terhadap penghindaran pajak.

Skor rata-rata variabel Kualitas Audit (X3) ditemukan sebesar 1,49 dimana dari 150 data yang diamati terdapat sebanyak 77 data observasi $(51,3 \%)$ diaudit oleh Kantor Akuntan Publik (KAP) The Big Four yaitu Price Waterhouse Cooper-PWC, Deloitte Touche Tohmatsu, KPMG, Ernst \& YoungE\&Y, dan sebanyak 73 data observasi $(48,7 \%)$ diaudit oleh Non-Kantor Akuntan Publik (KAP) The Big Four. Berdasarkan hasil pengujian hipotesis ketiga (H3) diperoleh koefisien regresi variabel Kualitas Audit (X3) 
sebesar -0,086 dan signifikan 0,000 dimana nilai signifikan tersebut lebih kecil dari 0,05. Dengan demikian dapat disimpulkan bahwa variabel Kualitas Audit (X3) berpengaruh negatif dan signifikan terhadap tax avoidance (Y).

Temuan penelitian ini bermakna bahwa tinggi atau rendahnya variasi penghindaran pajak (tax avoidance) ditentukan oleh Kualitas Audit. Dengan kata lain, apabila semakin banyak perusahaan sampel terpilih diaudit oleh Kantor Akuntan Publik (KAP) The Big Four maka akan semakin rendah tax avoidance. Namun sebaliknya, apabila semakin sedikit perusahaan sampel terpilih diaudit oleh Kantor Akuntan Publik (KAP) The Big Four maka akan semakin tinggi tax avoidance. Temuan penelitian ini mendukung hasil peneltian terdahulu (Annisa \& Kurniasih, 2012; Maharani \& Suardana, 2014; Dewi \& Jati, 2014) dimana penelitian terdahulu tersebut membuktikan secara empiris bahwa variabel Kualitas Audit berpengaruh negatif dan signifikan terhadap tax avoidance.

Skor rata-rata variabel Komite Audit (X4) sebesar 3,13 dimana dari 150 data obeservasi masih ditemukan sebanyak 4,7\% data observasi yang belum memenuhi Peraturan Bank Indonesia No. 8/14/PBI/2006 tentang pelaksanaan good corporate govenance yaitu jumlah anggota Komite Audit minimal 3 orang. Selanjutnya hasil analisis deskriptif menemukan sebanyak $81,3 \%$ memiliki jumlah anggota Komite Audit sebanyak 3 orang, $10 \%$ memiliki jumlah anggota Komite Audit 4 orang, dan $4 \%$ memiliki jumlah anggota Komite Audit 5 orang. Temuan ini memberikan makna bahwa sebanyak 95,3\% data observasi telah memiliki jumlah anggota Komite Audit 3 orang atau lebih. Berdasarkan hasil pengujian hipotesis keempat (H4) diperoleh koefisien regresi variabel Komite Audit (X4) sebesar -0,132 dan signifikan 0,000 dimana nilai signifikan tersebut lebih kecil dari 0,05. Dengan demikian dapat disimpulkan bahwa variabel Komite Audit (X4) berpengaruh negatif dan signifikan terhadap tax avoidance (Y). Temuan penelitian ini bermakna bahwa tinggi atau rendahnya variasi penghindaran pajak (tax avoidance) ditentukan oleh Komite Audit. Dengan kata lain, apabila semakin banyak jumlah anggota Komite Audit maka akan semakin rendah tax avoidance. Namun sebaliknya, apabila semakin sedikit jumlah anggota Komite Audit maka akan semakin tinggi tax avoidance. Temuan penelitian ini mendukung hasil peneltian terdahulu (Maharani dan Suardana 2014; Dewi dan Jati 2014) dimana para peneliti terdahulu tersebut membuktikan secara empiris bahwa variabel Komite Audit berpengaruh negatif dan signifikan terhadap tax avoidance.

\section{SIMPULAN}

Berdasarkan hasil analisis yang telah dilakukan sebelumnya, maka dapat penulis sampaikan beberapa kesimpulan dari penelitian sebagai berikut: (1) Kepemilikan Institutional (KI) tidak berpengaruh signifikan terhadap tax avoidance; (2) Proporsi Komisaris Independen berpengaruh negatif dan signifikan terhadap tax avoidance; (3) Kualitas Audit berpengaruh negatif dan signifikan terhadap tax avoidance, dan; (4) Komite audit berpengaruh negatif dan signifikan terhadap tax avoidance.

\section{Limitations and Directions for Future Research}

Beberapa keterbatasan dalam penelitian ini dapat disampaikan sebagai berikut: (1) Objek penelitian ini adalah perusahaan manufaktur yang terdaftar di Bursa Efek Indonesia (BEI) pada periode 2011-2013 dan hanya membatasi pada tiga sektor yaitu industri \& kimia (Porselin, Kertas, Kimia, Logam Pakan Ternak, Plastik, Semen), aneka industri (Alas Kaki, Kabel, Otomotif, Tekstil \& Garmen), dan barang konsumsi (Farmasi, Kosmetik, Makanan \& Minuman, Peralatan RT, Rokok); (2) Penelitian ini hanya mengkonsepkan CG berdasarkan Kepemilikan Institutional, Proporsi Komisaris Independen, Kualitas Audit, dan Komite Audit sebagai determinan tax avoidance.

Berpedoman kepada beberapa keterbatasan penelitian yang telah disampaikan 
diatas, maka penulis memberikan saran-saran bagi peneliti yang akan datang sebagai berikut: (1) Peneliti yang akan datang dapat mereplikasi model penelitian ini dan selanjutnya mengujikan pada industri lainnya seperti pertambangan (mining), agrikultur (agriculture), dan jasa (service); (2) Peneliti yang akan datang dapat mempertimbangkan variabel lain dalam konsep CG seperti variabel managerial incentives, karakteristik eksekutif (resiko perusahaan), kepemilikan keluarga dan lain lain.

\section{DAFTAR REFERENSI}

Annisa, N.A., dan L. Kurniasih. 2012. Pengaruh corporate governance terhadap tax avoaidance. Jurnal Akuntansi \& Auditing 8 (2): 95-189.

Armstrong, C.S., J.L. Blouin, A.D. Jagolinzer, dan D.F. Larcker. 2013. Corporate Governance, incentives, and tax avoidance. Rock Center for Corporate Governance Stanford University, Working Paper Series No. 136. Diakses dari http://ssrn.com/abstract=2252682.

Chai, H., dan Q. Liu. 2009. Competition and corporate tax avoidance: Evidence from Chinese industrial firms. Economic Journal 119 (537): 764-795.

Daniri, M. A. 2006. Good Corporate Governance: Konsep dan penerapannya dalam konteks Indonesia. eds kedua. Jakarta: PT. Ray Indonesia.

Darmawan, I. G. H., dan I. M. Sukartha. 2014. Pengaruh penerapan Corporate Governance, Leverage, ROA dan ukuran perusahaan pada penghindaran pajak. E-Jurnal Akuntansi 9 (1): 143-161.

Desai, M.A., dan D. Dharmapala. 2006. Corporate tax avoidance and high powered incentives." Journal of Financial Economics 79 (1): 145-179.

Dewi, N.N., dan I.K. Jati. 2014. Pengaruh karakteristik eksekutif, karakteristik perusahaan, dan dimensi tata kelola perushaan yang baik pada tax avoidance di Bursa Efek Indonesia. EJurnal Akuntansi 6 (2): 249-260.

Dyreng, S., M. Hanlon, dan E. L. Maydew. 2008. Long-run corporate tax avoidance. The Accounting Review 83 (2): 61-82.

Fernandes, V.L., A.L. Martinez, dan V. Nossa. 2013. The Influence of the best Corporate Governance practices on the allocation of value added to taxes: A Brazilian case contabilidade, gestão e governança. Brasilia 16 (3).

James, O.K., dan E.I. Igbeng. 2014. Corporate Governance, shareholders wealth maximization and tax avoidance. Research Journal of Finance and Accounting 5 (2): 127-130.

Kementerian BUMN, 2012. Keputusan sekretaris Kementerian Badan Usaha Milik Negara No. SK-16/S.MBU/2012 tentang indikator/parameter penilaian dan evaluasi atas penerapan tata kelola perusahaan yang baik (Good Corporate Governance) pada Badan Usaha Milik Negara.

Khoala, A. 2013. Does Corporate Governance affect tax planning? Evidence from American companies. International Journal of Advanced Research 1 (10): 864-873.

Khurana, I.K., dan W.J. Moser. 2009. Institutional Ownership and Tax Aggressiveness. Diakses dari www.ssrn.com.

Kurniasih, T., dan M. Sari. 2013. Pengaruh ROA, leverage, Corporate Governance, ukuran perushaan, dan kompensasi rugi fiskal terhadap tax avoidance. Buletin Studi Ekonomi 18 (1): 1-84.

Lanis, R., dan G. Richardson. 2011. The Effect of board of director composition on corporate tax aggressiveness. Journal of Accounting \& Public Policy 30 (1): 50-70. 
Lukviarman, N. 2006. Etika bisnis tidak berjalan di Indonesia: Ada apa dalam Corporate Governance? Jurnal Siasat Bisnis 9 (2): 139-156.

Maharani, I.G., dan K.A. Suardana. 2014. Pengaruh Corporate Governance, profitabilitas, dan karakteristik eksekutif pada tax evoidance. E-Jurnal Akuntansi9 (2): 525 -539.

Mayangsari, S. 2003. Analisis pengaruh independensi, kualitas audit, serta mekanisme Corporate Governance terhadap integritas laporan keuangan. Surabaya: Simposium Nasional Akuntansi VI.

Minnick, K., dan T. Noga. 2010. Do Corporate Governance characteristics influence tax management? Journal of Corporate Finance 16 (5): 703-718.

Pohan, H. T. 2008. Pengaruh Good Corporate Governance, rasio Tobin $Q$, perata laba terhadap penghindaran pajak pada perusahaan publik Jakarta: Fakultas Ekonomi Universitas Trisakti.

Prakosa, K. B. 2014. Pengaruh profitabilitas, kepemilikan keluarga dan Corporate Governance terhadap penghindaran pajak di Indonesia. Mataram: Simposium Nasional Akuntansi XVII.

Rego, S.O., dan R. Wilson. 2008. Executive Compensation, Tax Reporting Aggressiveness, and Future Firm Performance. Diakses dari http://areas.kenanflagler.unc.edu/Accounting/TaxCenter/ taxsym09/Documents/Rego and\%2 0Wilson 2008.pdf.

Republik Indonesia. 2007. Undang-Undang Republik Indonesia Nomor 40 tahun 2007 tentang Perseroan Terbatas.

Sabli, N., dan R.M. Noor. 2012. Tax planning and Corporate Governance. In The 3rd International Conference on Business and Economic Research (3rd ICBER 2012) Proceeding.
Sartori, N. 2010. Effect of strategic tax behavior on Corporate Governance. www.ssrn.com.

Sekaran, U., dan R. Bougie. 2010. Research Methods for Business. A Skill Building Approach. John Wiley and Sons, Ltd.

Setiana, D., dan W. Setyowati. 2014. Pengaruh Corporate Governance, kompensasi rugi fiskal, ROA, leverage dan ukuran perusahaan terhadap tax avoidance. Journal Accounting and Banking 3 (2).

Shafer, W., dan R. Simmons. 2006. Social responsibility, machiavellianism and tax avoidance: A Study of Hong Kong tax professionals. Working Paper No.5.

Siallagan, H., dan M. Machfoedz. 2006. Mekanisme Corporate Governance, Kualitas laba dan nilai perusahaan. Padang: Simposium Nasional Akuntansi IX.

Solomon, J. 2007. Corporate Governance and accountability. 2nd ed. The Atrium, West Sussex: John Wiley \& Sons, Ltd.

Tarjo. 2008. Pengaruh konsentrasi kepemilikan institusional dan leverage terhadap manajemen laba, nilai pemegang saham serta cost of equity capital. Pontianak: Simposium Nasioanal Akuntansi XI.

Timothy, Y. C. K. 2010. Effects of Corporate Governance on tax avoidance. Hong Kong Baptist University. Diakses dari www.libsca.hkbu.edu.hk/trsimage/hp/07014341 .pdf.

Tuanakotta, T. M. 2007. Setengah abad profesi akuntansi. Jakarta: Badan Penerbit Salemba Empat.

Wardani, D. K. 2008. Pengaruh Corporate Governance terhadap kinerja perusahaan di Indonesia. Yogyakarta: Universitas Islam Indonesia. 